\title{
PERLINDUNGAN HUKUM TERHADAP ANAK SEBAGAI PENYALAHGUNA NARKOTIKA DALAM SISTEM PERADILAN PIDANA ANAK DI INDONESIA
}

\author{
Beniharmoni Harefa \\ Fakultas Hukum, Universitas Pembangunan Nasional (UPN) "Veteran" Jakarta \\ e-mail:beni_harefa@yahoo.com
}

\begin{abstract}
ABSTRAK
Dalam sistem peradilan pidana anak di Indonesia, anak sebagai penyalahguna narkotika, menjalani proses peradilan pidana. Sebagai pihak yang rentan dalam proses peradilan pidana, maka meski menjalani proses peradilan, kiranya anak tetap harus mendapat perlindungan. Bagaimana bentuk perlindungan serta apa faktor yang menjadi penghambat upaya perlindungan hukum terhadap anak sebagai penyalahguna narkotika dalam sistem peradilan pidana, menjadi pertanyaan yang akan dibahas dalam penelitian ini. Metode yang digunakan yakni metode penelitian yuridis normatif, yaitu penelitian terhadap data sekunder. Perlindungan hukum terhadap anak sebagai penyalahguna narkotika di Indonesia, diatur dalam UndangUndang Nomor 11 Tahun 2012 tentang Sistem Peradilan Pidana Anak, Undang-Undang Nomor 35 Tahun 2009 tentang Narkotika, dan Undang-Undang Nomor 17 Tahun 2016 tentang Penetapan Peraturan Pemerintah Pengganti Undang-Undang Nomor 1 Tahun 2016 tentang Perubahan Kedua Atas UndangUndang Nomor 23 Tahun 2002 tentang Perlindungan Anak, serta berbagai peraturan perundang-undangan teknis lainnya yang berkaitan tentang anak sebagai penyalahguna narkotika. Upaya perlindungan pada anak sebagai penyalahguna narkotika, dilakukan melalui upaya diversi, bertujuan menghindarkan anak dari proses peradilan pidana formal ke peradilan pidana non formal. Perlindungan lainnya dengan pengawasan, pencegahan, perawatan, dan rehabilitasi terhadap anak penyalahguna narkotika. Faktor penghambat, pertama, kurangnya pemahaman dari aparat penegak hukum, kedua, kurangnya pemahaman masyarakat dan ketiga, kurangnya fasilitas khususnya di daerah-daerah terpencil di Indonesia.
\end{abstract}

Kata Kunci: perlindungan hukum, anak sebagai penyalahguna narkotika, sistem peradilan pidana.

\begin{abstract}
In the Indonesian juvenile justice system, children of drug abusers undergo trial. As a vulnerable person in the criminal justice system, then despite the judicial process, presumably the child should still be protected. How the form of protection as well as what factors are inhibiting legal protection of the child as a narcotics abuser in the criminal justice system, the question that will be discussed in this study. The method used is normative juridical research method, that is research on secondary data. The legal protection to the children of narcotics abusers in Indonesia is regulated in the Act No. 11 of the Year 2012 on Juvenile Justice System, the Act No. 35 of 2009 on Narcotics, and the Act No. 17 of the Year 2016 on Stipulation of Government Regulation in Lieu of Law No. 1 of 2016 on the Second Amendment to the act No. 23 of 2002 on Protection of Children, as well as other technical regulations relating to narcotics abuser children. Protection efforts on children of drug abusers are carried out through surveillance, prevention, treatment, and rehabilitation. Diversion efforts, aim to prevent children from formal juvenile justice processes to non-formal juvenile justice. Factors inhibiting the legal protection of drug abuser children are, firstly, the lack of understanding of the law enforcement from the officers; secondly, the lack of understanding of the community; thirdly, the lack of facilities, especially in remote areas of Indonesia. Keyword: legal protection, narcotics abuser children, juvenile justice system.
\end{abstract}




\section{PENDAHULUAN}

Anak merupakan harapan bangsa, sebagai generasi penerus, diperlukan pembinaan dan perlindungan secara terus menerus demi kelangsungan hidup, pertumbuhan dan perkembangan fisik, mental, sosial serta perlindungan dari segala kemungkinan yang akan membahayakan mereka (anak) dan di masa depan. Narkotika dan obat-obatan terlarang lainnya, menjadi salah satu pemicu rusaknya anak. Anak sering menjadi target para pengedar narkotika, karena anak masih labil, mudah dipengaruhi sehingga berpotensi terjerat dalam penyalahgunaan obatobatan terlarang seperti narkotika.

Anak sebagai penyalahguna narkotika, hanyalah korban. Sehingga tidak sepatutnya, negara memberikan hukuman dengan memandang sama antara anak penyalahguna dengan penjahat dewasa (pengedar) yang sesungguhnya. Sebagai korban maka anak sebagai penyalahguna narkotika wajib mendapatkan perlindungan. Perlindungan anak merupakan usaha yang dilakukan untuk menciptakan kondisi agar setiap anak dapat melaksanakan hak dan kewajibannya demi perkembangan dan pertumbuhan anak secara wajar, baik fisik, mental, dan sosial. ${ }^{1}$

Dalam sistem peradilan pidana anak di Indonesia, anak sebagai penyalahguna narkotika, tetap menjalani proses peradilan. Proses peradilan tersebut untuk meminta pertanggungjawaban anak. Meski menjalani proses peradilan, namun kiranya anak tetap harus mendapat perlindungan. Adapun pertimbangan anak penyalahguna narkotika mendapat perlindungan, karena diyakini bahwa penyalahgunaan anak terhadap narkotika bukanlah sepenuhnya berasal dari diri anak, namun lebih kepada pengaruh dari lingkungan sekitar.

Penyimpangan tingkah laku atau perbuatan melanggar hukum yang dilakukan oleh anak, antara lain disebabkan oleh faktor di luar diri anak tersebut. ${ }^{2}$ Faktor di luar diri tersebut, termasuk lingkungan keluarga, lingkungan masyarakat, lingkungan pendidikan di mana anak berada. Lingkungan sekitar ini, memberi sumbangsih besar atas perkembangan nilai dan perilaku anak. Apabila lingkungan buruk,

${ }^{1}$ Maidin Gultom, Perlindungan Hukum Terhadap Anak Dalam Sistem Peradilan Pidana Anak di Indonesia, Refika Aditama, Bandung, 2008, h. 33.

${ }^{2}$ Alinea 2 Penjelasan Undang-Undang No. 11 Tahun 2012 tentang Sistem Peradilan Pidana Anak. maka dapat dipastikan memberikan pengaruh negatif pada nilai dan perilaku anak, sehingga berpotensi melakukan penyimpangan tingkah laku atau perbuatan melanggar hukum.

Penyimpangan tingkah laku atau perbuatan melanggar hukum termasuk penyalahgunaan narkotika. Berdasarkan Pasal 1 ayat (15) UndangUndang Nomor 35 Tahun 2009 tentang Narkotika (selanjutnya disingkat UU Narkotika), penyalahguna narkotika adalah orang yang menggunakan narkotika tanpa hak atau melawan hukum. Selanjutnya, Pasal 1 ayat 3 Undang-Undang Nomor 11 Tahun 2012 tentang Sistem Peradilan Pidana Anak (UU SPPA), menegaskan Anak yang berkonflik dengan hukum adalah anak yang telah berumur 12 (dua belas) tahun, tetapi belum berumur 18 (delapan belas) tahun yang diduga melakukan tindak pidana.

Anak sebagai penyalahguna narkotika yang dimaksud di dalam penelitian ini, yakni anak yang telah berumur 12 (dua belas) tahun, tetapi belum berumur 18 (delapan belas) tahun, yang diduga menggunakan narkotika tanpa hak atau melawan hukum. Sehingga yang dimaksud anak sebagai penyalahguna narkotika, adalah anak yang diduga melakukan tindak pidana narkotika. Meski diduga melakukan tindak pidana narkotika, namun anak tetaplah anak dengan segala kekurangan dan keterbatasan mereka. Oleh sebab itu, perlindungan terhadap anak sebagai penyalahguna narkotika merupakan hal yang penting.

\section{PERUMUSAN MASALAH}

Penelitian ini, hendak menjawab dua pertanyaan. Pertama, bentuk perlindungan yang diberikan kepada anak sebagai penyalahguna narkotika dalam sistem peradilan pidana anak di Indonesia. Kedua, faktor penghambat perlindungan hukum terhadap anak sebagai penyalahguna narkotika.

\section{METODE PENELITIAN}

Metode yang digunakan dalam penelitian ini yakni metode penelitian yuridis normatif. Jenis penelitian ini masuk dalam kategori penelitian kepustakaan, yaitu penelitian terhadap data sekunder. ${ }^{3}$ Data sekunder sebagai bahan dasar dalam penelitian

\footnotetext{
${ }^{3}$ Ronny Hanitijo Soemitro, Metode Penitian Hukum, Ghalia Indonesia, Jakarta, 1998, h. 11.
} 
ini, dapat berupa berbagai bahan hukum, baik bahan hukum primer maupun bahan hukum sekunder. ${ }^{4}$

Bahan hukum primer terdiri dari perundangundangan khususnya perundangan-undangan terkait narkotika, perlindungan anak, dan sistem peradilan pidana anak. Bahan hukum sekunder terdiri dari buku-buku teks, jurnal-jurnal hukum, khususnya buku dan jurnal terkait narkotika, perlindungan anak dan sistem peradilan pidana anak. Data yang terkumpul akan dianalisis secara deskriptif dan preskriptif.

\section{PEMBAHASAN}

\section{Bentuk Perlindungan Bagi Anak Penyalahguna Narkotika}

Upaya perlindungan hukum terhadap anak dapat dilakukan dalam bentuk perlindungan terhadap kebebasan dan hak asasi anak atau fundamental rights and freedoms of children. ${ }^{5}$ Hak-hak anak berdasarkan Konvensi Hak Anak, ${ }^{6}$ dapat dirumuskan sebagai berikut, yaitu: the right to survival atau hak terhadap kelangsungan hidup; the right to develop atau hak untuk tumbuh kembang; the right to protection atau hak terhadap perlindungan; the right to participation atau hak untuk berpartisipasi.

Perlindungan hukum terhadap hak-hak anak tersebut, bermaksud untuk melindungi berbagai kepentingan yang berhubungan dengan kesejahteraan anak. Salah satu bentuk perlindungan hukum bagi hak asasi anak, yaitu perlindungan hukum terhadap anak yang berada dalam sistem peradilan pidana anak.

Dalam rangka memaksimalkan perlindungan bagi anak di Indonesia, khususnya perlindungan hukum maka diterbitkan Undang-Undang Nomor 23 Tahun 2002 tentang Perlindungan Anak. Seiring perkembangan, maka Undang-undang Perlindungan Anak ini kemudian diubah melalui Undang-Undang

\footnotetext{
${ }^{4}$ Peter Mahmud Marzuki, Penelitian Hukum (Edisi Revisi), Kencana Prenada Media Grup, Jakarta, 2010, h. 181.

${ }^{5}$ Barda Nawawi Arief, Beberapa Aspek Kebijakan dan Pengembangan Hukum Pidana, Citra Aditya, Bandung, 1998, h. 153.

${ }^{6}$ Convention on The Rights of The Child atau Konvensi Hak Anak (Berdasarkan Resolusi PBB Nomor 44/25 tanggal 5 Desember 1989) konvensi ini telah diratifikasi oleh Indonesia melalui Keputusan Presiden Nomor 36 tahun 1990 tentang Pengesahan Konvensi tentang Hak-Hak Anak (KHA), lihat M. Farid dkk., Pengertian Konvensi Hak Anak, UNICEF, Jakarta, 2003, h. 2.
}

Nomor 35 Tahun 2014 tentang Perubahan Atas Undang-Undang Nomor 23 Tahun 2002 tentang Perlindungan Anak (selanjutnya disingkat UU Perlindungan Anak).

Di tahun 2016, dengan meningkatnya kasuskasus kekerasan utamanya kekerasan seksual terhadap anak maka diterbitkan Peraturan Pengganti Undang-Undang (Perppu) tentang Perlindungan Anak. Perppu tersebut selanjutnya ditetapkan sebagai undang-undang melalui Undang-Undang Nomor 17 Tahun 2016 tentang Penetapan Peraturan Pemerintah Pengganti Undang-Undang Nomor 1 Tahun 2016 tentang Perubahan Kedua Atas Undang-Undang Nomor 23 Tahun 2002 tentang Perlindungan Anak.

Dari perjalanan panjang pembentukan UU Perlindungan Anak tersebut, terlihat bahwa negara memberikan perhatian serius terhadap masalah perlindungan anak di Indonesia. Perhatian serius ini dalam rangka melindungi dan menegakkan hak-hak anak, termasuk anak penyalahguna narkotika. Dalam UU Perlindungan Anak telah ditentukan adanya perlindungan khusus bagi anak yang menjadi korban penyalahgunaan narkotika, alkohol, psikotropika, dan zat adiktif lainnya (napza).

Pemerintah dan lembaga negara lainnya berkewajiban dan bertanggungjawab untuk memberikan perlindungan khusus kepada anak salah satunya adalah anak yang menjadi korban penyalahgunaan narkotika, alkohol, psikotropika, dan zat adiktif lainnya (napza). ${ }^{7}$

Selain itu, Indonesia juga memiliki UU Narkotika, mengatur bahwa pemerintah melakukan pembinaan segala kegiatan yang berhubungan dengan narkotika meliputi upaya mencegah perlibatan anak di bawah umur dalam penyalahgunaan dan peredaran gelap narkotika. Mencegah generasi muda dan anak usia sekolah dalam penyalahgunaan narkotika, termasuk dengan memasukkan pendidikan yang berkaitan dengan narkotika dalam kurikulum sekolah dasar sampai lanjutan atas. ${ }^{8}$

Dalam sistem peradilan pidana anak di Indonesia, berdasarkan UU SPPA, maka setiap anak yang melakukan tindak pidana, dimungkinkan untuk diperhadapkan dalam proses peradilan layaknya pelaku tindak pidana lainnya. Termasuk anak

\footnotetext{
${ }^{7}$ Pasal 67 ayat (1) UU Perlindungan Anak.

${ }^{8}$ Pasal 60 ayat (2c) UU Narkotika.
} 
penyalahguna narkotika, dapat diperhadapkan dalam sistem peradilan pidana formal.

Sistem peradilan pidana anak dapat diartikan sebagai segala unsur sistem peradilan pidana, yang terkait di dalam penanganan kasus-kasus kenakalan anak. Pertama, polisi sebagai institusi formal ketika anak nakal pertama kali bersentuhan sistem peradilan. Kedua, jaksa dan lembaga pembebasan bersyarat yang akan menentukan apakah anak akan dibebaskan atau diproses ke pengadilan anak. Ketiga, pengadilan anak, tahapan ketika anak akan ditempatkan dalam pilihan-pilihan, mulai dari dibebaskan sampai dimasukkan dalam institusi penghukuman. Keempat atau yang terakhir ialah institusi penghukuman. ${ }^{9}$

Sistem peradilan anak meliputi segala aktifitas pemeriksaan dan pemutusan perkara yang menyangkut kepentingan anak. Yaitu segala aktivitas yang dilakukan oleh polisi, jaksa, hakim dan pejabat lain, harus didasarkan pada suatu prinsip ialah demi kesejahteraan anak dan kepentingan anak. ${ }^{10}$ Dengan demikian, sistem peradilan pidana anak, meliputi segala aktivitas pemeriksaan dan pemutusan perkara anak, yang dilakukan sejak penyelidikan/penyidikan oleh polisi, penuntutan oleh jaksa, persidangan di pengadilan oleh hakim dan penghukuman oleh lembaga pemasyarakatan, seluruh rangkaian aktifitas ini tentunya dilakukan dengan mempertimbangkan kepentingan anak.

Sebagai pihak rentan, banyak dampak buruk bagi anak (khususnya anak pelaku tindak pidana) apabila ditempatkan dalam proses peradilan pidana. Adapun dampak buruk tersebut, antara lain berupa tindak kekerasan. Tindak kekerasan berupa fisik, psikis maupun seksual. Kekerasan fisik, antara lain: pemukulan, penyiksaan, digunduli rambutnya, ditampar, disulut rokok, ditempatkan di tahanan campur dengan pelaku kejahatan orang dewasa, atau tindakan lain yang kejam dan tidak manusiawi lainnya, sering dijumpai anak. ${ }^{11}$

${ }^{9}$ Mamik Sri Supatmi Purnianti dan Ni Made Martini Tinduk, Analisa Sistem Peradilan Pidana Anak (Juvenile Justice System), Departemen Kriminologi, Fisip Universitas IndonesiaUNICEF, Jakarta, 2003, h. 5.

10 Sudarto, Kapita Selekta Hukum Pidana, Alumni, Bandung, 2010, h. 129 dan 140.

${ }^{11}$ Paulus Hadisuprapto, "Pemberian Malu Reintegratif Sebagai Sarana Non Penal Penanggulangan Perilaku Delinkuensi Anak (Studi Kasus di Semarang dan Surakarta)", Disertasi Ilmu Hukum, Universitas Diponegoro, Semarang, 2003.
Kekerasan psikis antara lain: bentakan, pengancaman, caci maki, kata-kata kotor, hinaan, dan sebagainya. pengaruh psikologis atau kejiwaan juga akan berdampak negatif pada anak, akibat proses peradilan pidana. Kekerasan psikis ini dapat menimbulkan trauma bagi anak. Kekerasan seksual, antara lain: pemerkosaan, pencabulan, penyiksaan, pelecehan seksual.

Dampak buruk lainnya, proses peradilan pidana berbekas dalam ingatan anak. Pengalaman menjalani rangkaian proses peradilan yang melelahkan, akan berbekas di dalam ingatan anak. Efek negatif itu dapat berupa ketakutan, kegelisahan, gangguan tidur, gangguan nafsu makan maupun gangguan jiwa. Akibatnya anak menjadi gelisah, tegang, kehilangan kontrol emosional, menangis, gemetaran, malu, dan sebagainya. Efek negatif pun berlanjut setelah anak dijatuhi putusan pemidanaan, seperti stigma yang

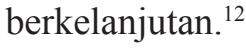

Dampak buruk proses peradilan pidana formal, juga dapat berupa trauma, stigma, dan anak dikeluarkan dari sekolah. ${ }^{13}$ Berbagai kekerasan yang diterima anak, menimbulkan trauma. Stigma atau cap jahat pada diri anak pelaku kenakalan juga melekat, sehingga anak tersebut selalu dikhawatirkan akan berbuat jahat lagi.

Anak juga berpotensi dikeluarkan dari sekolah, karena untuk menghadapi proses hukum yang membelitnya, anak terpaksa harus beberapa kali ke kantor polisi ataupun tidak datang sekolah. Pihak sekolah tentunya mempunyai aturan terkait kehadiran, apabila jumlah kehadiran anak tidak memenuhi, maka pihak sekolah akan memberikan sanksi tegas pada anak.

Menurut Apong Herlina, dampak buruk tersebut, dapat digambarkan, sebagai berikut: ${ }^{14}$ Pertama, pada tahap pra persidangan. Pengaruh buruk terhadap anak berupa ketakutan, kegelisahan, gangguan tidur, gangguan nafsu makan maupun dapat menjadi

\footnotetext{
${ }^{12}$ Apong Herlina dkk., Perlindungan Terhadap Anak yang Berhadapan Dengan Hukum, Manual Pelatihan untuk Polisi, POLRI dan UNICEF, Jakarta, 2004, h. 101-103.

${ }^{13}$ Setya Wahyudi, Johannes Suhardjana, Kuat Puji Prayitno, dan Dwi Hapsari Retnaningrum, "Pengembangan Diversi Dalam Sistem Peradilan Pidana Anak sebagai Perlindungan dan Upaya Menghindari Pengaruh Buruk Proses Peradilan Terhadap Anak", Jurnal Kertha Wicaksana, Vol. 15 No. 1, Januari 2009, Universitas Warmadewa Denpasar, Bali, h. 23.

${ }^{14}$ Apong Herlina, Ibid.
} 
gangguan jiwa. Dampak buruk lainnya yaitu pemeriksaan medis, pertanyaan yang tidak simpatik, diulang-ulang dan kasar, dan tidak berperasaan oleh petugas pemeriksa, harus menceritakan kembali pengalaman atau peristiwa yang tidak menyenangkan, dan melakukan rekonstruksi, wawancara dan pemberitaan oleh media, menunggu persidangan, proses persidangan tertunda, pemisahan dari keluarga atau tempat tinggal.

Kedua, pada tahap persidangan. Pengaruh buruk berupa: anak menjadi gelisah, menangis, malu, depresi, gangguan berpikir dan lain-lain, yaitu menunggu dalam ruangan pengadilan, kurang pengetahuan tentang proses yang berlangsung, tata ruang sidang, berhadapan dengan saksi dan korban, berbicara dihadapan para petugas pengadilan, proses pemeriksaan dalam sidang. Ketiga, atau yang terakhir, pada tahap setelah persidangan. Dampak buruk berupa: putusan hakim, tidak adanya tindak lanjut, stigma yang berkelanjutan, rasa bersalah, kemarahan dari pihak keluarga. Keseluruhan pengaruh atau dampak buruk tersebut, harus dijalani anak saat ditempatkan di dalam proses peradilan pidana, akibat mempertanggungjawabkan perbuatan nakalnya.

Menghindari dampak buruk tersebut, maka UU SPPA mengakomodir program yang dinamakan diversi. Secara singkat diversi adalah pengalihan penyelesaian perkara anak dari proses peradilan pidana ke proses di luar peradilan pidana. ${ }^{15}$ Menurut Jack E. Bynum, diversion is an attempt to divert or channel out, youthful offenders from the juvenile justice system. ${ }^{16}$ Diversi merupakan suatu tindakan atau perlakuan untuk mengalihkan atau menempatkan pelaku tindak pidana anak, termasuk anak penyalahguna narkotika, keluar dari sistem peradilan.

Diversi dapat berbentuk, perdamaian dengan atau tanpa kerugian, penyerahan kembali kepada orangtua atau wali, keikutsertaan dalam pendidikan atau pelatihan dan pelayanan masyarakat. ${ }^{17}$ Adapun yang menjadi syarat diversi, yakni diversi dapat dilakukan pada anak yang melakukan tindak pidana yang diancam dengan pidana penjara di bawah 7

\footnotetext{
15 Pasal 1 ayat (7) UU SPPA.

16 Jack E. Bynum dan William E. Thompsson, Juvenile Delinquency a Social Approach, Allyn and Bacon A Peason Education Company, Boston, 2002, h. 430.

17 Pasal 11 UU SPPA.
}

(tujuh) tahun dan bukan merupakan pengulangan tindak pidana. ${ }^{18}$

Anak penyalahguna narkotika, apabila ditempatkan di dalam sistem peradilan pidana formal, dapat dipastikan akan mengalami dampak buruk. Hal ini jelas, melanggar hak-hak anak. Melalui diversi, anak penyalahguna narkotika mendapatkan perlindungan. Diversi memberikan perlindungan atas hak-hak asasi anak. ${ }^{19}$ Oleh sebab itu, diversi merupakan salah satu upaya perlindungan hukum bagi anak penyalahguna narkotika, untuk menghindari anak dari dampak buruk proses peradilan pidana, sebagaimana diatur dalam UU SPPA.

Bentuk diversi terhadap anak sebagai penyalahguna narkotika dimungkinkan dengan penyerahan kembali kepada orangtua/wali atau keikutsertaan dalam pendidikan dan pelatihan dan pelayanan masyarakat. Kewenangan penilaian ini, tentunya berada di wilayah penyidikan yakni Kepolisian Republik Indonesia (Polri) atau Badan Narkotika Nasional/Daerah (BNN/D). Sehingga anak benar-benar mendapat perlindungan. Anak penyalahguna narkotika di diversi (dialihkan), dengan menolong si anak agar terbebas dari jeratan narkotika di masa mendatang.

Narkotika digolongkan menjadi tiga golongan sebagaimana tertuang dalam Pasal 6 UU Narkotika. Narkotika golongan I, golongan II dan golongan III. Penggolongan narkotika menjadi tiga macam didasarkan pada tingkat khasiat obat, tujuan, dan potensi menimbulkan ketergantungan. Dalam bagian Penjelasan dan Lampiran I UU Narkotika, disebutkan definisi dan jenis-jenis narkotika tersebut.

Jenis-jenis narkotika juga disebutkan dalam Peraturan Menteri Kesehatan Nomor 13 Tahun 2014 tentang Perubahan Penggolongan Narkotika. Keseluruhan penggolongan narkotika tersebut, juga sangat berdampak pada penerapan hukum terhadap anak penyalahguna narkotika.

Dalam praktek, setidak-tidaknya terdapat dua pasal yang acapkali digunakan dalam menjerat anak pelaku tindak pidana narkotika. Yakni Pasal 111 dan Pasal 127 UU Narkotika. Pasal 111 mengatur

\footnotetext{
18 Pasal 7 ayat (2) UU SPPA.

19 Beniharmoni Harefa, Vivi Ariyanti, Seputar Perkembangan Sistem Peradilan Pidana Anak dan Tindak Pidana Narkotika di Indonesia, Deepublish, Yogyakarta, 2016. h. 85 .
} 
setiap orang yang tanpa hak atau melawan hukum menanam, memelihara, memiliki, menyimpan, menguasai, atau menyediakan narkotika golongan I dalam bentuk tanaman, dipidana dengan pidana penjara paling singkat 4 (empat) tahun dan paling lama 12 (dua belas) tahun. Sedangkan, Pasal 127 mengatur setiap penyalah guna narkotika golongan I, II, III bagi diri sendiri dipidana dengan pidana penjara masing-masing paling lama 4 (empat) tahun, 2 (dua) tahun, dan 1 (satu) tahun.

Jika melihat kedua pasal tersebut, Pasal 111 pelaku diancaman dengan pidana penjara paling lama 12 (dua belas) tahun, maka ancaman pidananya, di atas 7 (tujuh) tahun atau melebihi yang dipersyaratkan dalam diversi. Pasal 127 pelaku diancam dengan pidana penjara paling lama 4 (empat) tahun atau di bawah 7 (tujuh) tahun dan wajib dilakukan diversi. Sehingga, Pasal 127 merupakan pasal yang paling memungkinkan untuk dilakukan diversi. Pasal 111 UU Narkotika, tidak memenuhi syarat diversi sedangkan Pasal 127 undang-undang a quo, memenuhi syarat untuk dilakukannya diversi. Selain diversi, maka perlindungan hukum terhadap anak penyalahguna narkotika yang berada dalam sistem peradilan pidana anak di Indonesia, dapat dilakukan dengan rehabilitasi. Jika seorang anak dinyatakan telah menyalahgunakan narkotika, maka berdasarkan aturan perundang-undangan, anak tersebut wajib untuk direhabilitasi.

Orangtua atau wali dari pecandu narkotika yang belum cukup umur wajib melaporkan kepada pusat kesehatan masyarakat, rumah sakit, dan/atau lembaga rehabilitasi medis dan rehabilitasi sosial yang ditunjuk oleh Pemerintah untuk mendapatkan pengobatan dan/atau perawatan melalui rehabilitasi medis dan rehabilitasi sosial. ${ }^{20}$ Secara umum upaya rehabilitasi ini dibagi dalam tiga tahap, yaitu: tahap detoksifikasi, tahap rehabilitasi dan tahap pembinaan.

Pertama, tahap detoksifikasi, yaitu tahap untuk menghilangkan racun yang berasal dari zat narkotika dalam tubuh korban sampai benar-benar tidak diketemukan zat narkotika dalam tubuh korban.

Kedua, tahap rehabilitasi, yang terdiri dari: rehabilitasi mental, yaitu upaya untuk memberikan bimbingan dan konseling yang diberikan oleh para ahli, seperti dokter dan psikiater. Rehabilitasi fisik, yaitu upaya melakukan kegiatan-kegiatan

\footnotetext{
${ }^{20}$ Pasal 55 ayat (1) UU Narkotika.
}

jasmani untuk melupakan atau menjauhkan diri dari ketergantungan pada narkoba, seperti olah raga, kesenian dan kursus-kursus. Hal ini lebih kepada kegiatan-kegiatan yang positif serta memberikan kreatifitas terhadap anak korban penyalahguna narkotika, sehingga dapat melupakan atau menjauhkan dirinya dari ketergantungan obat-obat berbahaya tersebut, sekalipun upaya ini butuh proses yang cukup lama.

Ketiga, tahap pembinaan, yaitu pembinaan khusus setelah korban keluar dari perawatan dan dinyatakan sembuh. Dalam hal ini perlu kerjasama dari orangtua, petugas sosial, dan psikolog. Pembinaan ini meliputi memperbaiki kembali sikap dan tingkah laku korban yang sempat terganggu oleh pengaruh narkoba, dan mempersiapkan diri untuk kembali ke tengah-tengah masyarakat atau pergaulan sosial.

Korban penyalahgunaan narkoba ini cenderung bersikap berbeda dari sebelum mengkonsumsi narkoba baik secara kejiwaan maupun dalam berpikir, oleh karenanya diperlukan pembinaan agar sikap dan perilakunya dapat pulih kembali sehingga berkepribadian untuk dapat kembali dalam pergaulan sosial. Dalam hal rehabilitasi ini juga pemerintah menyediakan fasilitas rehabilitasi sosial bekas pecandu narkotika yang dilakukan pada lembaga rehabilitasi sosial. ${ }^{21}$ Selanjutnya juga, perlindungan hukum yang dilakukan pemerintah terhadap anak penyalahguna narkotika yakni dengan perlindungan khusus.

Perlindungan khusus yang dimaksud dilakukan melalui upaya penanganan yang cepat, termasuk pengobatan dan atau rehabilitasi secara fisik, psikis, dan sosial, serta pencegahan penyakit dan gangguan kesehatan lainnya. Pendampingan psikososial pada saat pengobatan sampai pemulihan. Pemberian bantuan sosial bagi anak yang berasal dari keluarga tidak mampu. Pemberian perlindungan dan pendampingan pada setiap proses peradilan.

Upaya perlindungan pada anak penyalahguna narkotika, dilakukan melalui upaya pengawasan, pencegahan, perawatan, dan rehabilitasi oleh pemerintah dan masyarakat. Pengawasan dan pencegahan termasuk dalam upaya preventif atau pencegahan. Upaya pencegahan yang dapat dilakukan, diantaranya dengan mengendalikan peredaran segala

${ }^{21}$ Pasal 54-59 UU Narkotika. 
jenis obat dan makanan. Di Indonesia, lembaga yang diberi kewenangan khusus untuk ini yaitu Badan Pemeriksa Obat dan Makanan (BPOM). Aparat penegak hukum termasuk Polri dan BNN/D, harus sesering mungkin melakukan pengawasan terhadap tempat-tempat yang dianggap rawan beredarnya narkotika, seperti tempat hiburan malam, cafe, atau daerah-daerah tempat berkumpulnya anak muda dan remaja.

\section{Faktor Penghambat Perlindungan Hukum Terhadap Anak Dalam Sistem Peradilan Pidana di Indonesia}

Meski secara normatif, perlindungan hukum terhadap anak sebagai penyalahguna narkotika dalam sistem peradilan pidana anak di Indonesia telah diakomodir dan diatur melalui aturan perundangundangan, namun dalam hal penerapan dan pelaksanaannya menemui banyak kendala, beberapa faktor penghambat, diantaranya:

Pertama, kurangnya pemahaman dari aparat penegak hukum, bahwa anak sebagai penyalahguna narkotika hanyalah korban. Korban dari salah pergaulan, korban dari kurangnya perhatian orangtua, korban dari lingkungan yang tidak sehat. Sehingga, tidak jarang ditemukan beberapa kasus, aparat penegak hukum menerapkan pasal-pasal pemidanaan terhadap anak sebagai penyalahguna narkotika. Aparat penegak hukum yang dimaksud yakni aparat penegak hukum dalam sistem peradilan pidana anak di Indonesia. Dimulai dari tahap penyelidikan/ penyidikan yaitu kepolisian atau badan narkotika nasional/daerah. Pada tahap penuntutan adalah kejaksaan. Pada tahap sidang pengadilan adalah hakim. Pada tahap pelaksanaan putusan adalah petugas lembaga pemasyarakatan. Pemahaman para aparat penegak hukum tersebut, dapat diminimalisir, dengan memilih para aparat baik polisi, jaksa, hakim dan petugas lapas yang benar-benar memahami filosofi perlindungan anak. Kurangnya pemahaman aparat penegak hukum ini juga, mempengaruhi proses diversi atau pengalihan terhadap perkara pidana anak penyalahguna narkotika. Diversi yang seharusnya digunakan, sering tidak diterapkan. Sehingga kesempatan anak menjadi tertutup dan berpotensi menjadi penjahat sesungguhnya. Tidak jarang pasal yang diterapkan terhadap anak, adalah pasal yang tidak memungkinkan untuk didiversi atau dialihkan. Sehingga anak terpaksan harus berada dan mengikuti secara keseluruhan proses peradilan pidana formal, yang berdampak buruk bagi anak.

Kedua, yaitu kurangnya pemahaman masyarakat, bahwa anak penyalahguna narkotika adalah korban. Masyarakat yang terkesan masih menyamakan anak penyalahguna narkotika, sebagai penjahat sesungguhnya, yang sama dengan penjahat-penjahat narkotika dewasa, lainnya. Sehingga, pemahaman masyarakat ini, mempengaruhi upaya perlindungan hukum terhadap anak yang tidak maksimal. Stigma atau cap negatif dari masyarakat terhadap anak penyalahguna narkotika, akan menutup kesempatan bagi anak untuk kembali ke kehidupan normalnya. Stigma atau cap negatif hanya akan menegaskan bahwa anak penyalahguna narkotika, adalah benarbenar sebagai penjahat dan sulit atau bahkan tidak dapat lagi diperbaiki. Hanya dengan pemahaman yang benar, masyarakat dapat memberikan pengawasan yang positif kepada anak, sehingga terhindar dari penyalahgunaan narkotika.

Ketiga, yaitu kurangnya fasilitas khususnya di daerah-daerah terpencil di Indonesia. Khusus pada tahap rehabilitasi, melalui proses detoksifikasi, rehabilitasi mental, rehabilitasi fisik, pembinaan jasmani, pembinaan rohani, yang tidak semuanya terdapat di daerah-daerah di Indonesia. Hal ini dapat dimaklumi karena faktor geografis Indonesia, yang terdiri atas daerah-daerah kepulauan. Sehingga, perlindungan terhadap anak sebagai penyalahguna narkotika tidak optimal. Kurangnya fasilitas ini juga berupa lembaga-lembaga yang dipersyaratkan harus ada, sebagaimana diatur di dalam Undang-Undang SPPA. Seperti Lembaga Pembinaan Khusus Anak (LPKA), Lembaga Penempatan Anak Sementara (LPAS), Lembaga Penyelenggaraan Kesejahteraan Sosial (LPKS). Meski lembaga tersebut terdapat di beberapa wilayah di Indonesia, namun keberadaan lembaga-lembaga ini tidak merata. Sehingga, pelaksanaan diversi yang merupakan salah satu bentuk perlindungan hukum terhadap anak, tidak maksimal.

\section{PENUTUP \\ Kesimpulan}

Perlindungan hukum terhadap anak sebagai penyalahguna narkotika di Indonesia, diatur dalam UU SPPA, UU Narkotika, dan UU Perlindungan 
Anak, serta berbagai peraturan perundangundangan teknis lainnya yang berkaitan tentang anak penyalahguna narkotika.

Upaya perlindungan pada anak penyalahguna narkotika, dilakukan melalui upaya diversi, bertujuan menghindarkan anak dari proses peradilan pidana formal ke peradilan pidana non formal. Perlindungan lainnya dengan pengawasan, pencegahan, perawatan, dan rehabilitasi terhadap anak penyalahguna narkotika. Faktor penghambat perlindungan hukum terhadap anak penyalahguna narkotika adalah: pertama, kurangnya pemahaman dari aparat penegak hukum; kedua, kurangnya pemahaman masyarakat; ketiga, kurangnya fasilitas khususnya di daerahdaerah terpencil di Indonesia.

\section{Rekomendasi}

Anak penyalahguna narkotika hanyalah korban, sehingga tidak sepatutnya negara memberikan hukuman dengan memandang sama antara anak penyalahguna dengan penjahat dewasa (pengedar) yang sesungguhnya. Dalam sistem peradilan pidana anak di Indonesia, anak penyalahguna narkotika, tetap menjalani proses peradilan. Meski menjalani peradilan, namun kiranya anak tetap harus mendapat perlindungan.

Upaya perlindungan terhadap anak sebagai penyalahguna narkotika sebagai telah diatur di dalam berbagai aturan perundang-undangan, akan lebih maksimal, apabila peningkatan pemahaman aparat penegark hukum ditingkatkan serta peran serta masyarakat diperluas. Berbagai fasilitas utamanya lembaga pendukung perlindungan anak, harus menjadi perhatian serius pemerintah.

\section{DAFTAR PUSTAKA}

\section{Peraturan Perundang-undangan:}

Undang-Undang Nomor 35 Tahun 2009 tentang Narkotika, Lembaran Negara Tahun 2009 Nomor 143, Tambahan Lembaran Negara Tahun 2009 Nomor 5062.

Undang-Undang Nomor 11 Tahun 2012 tentang Sistem Peradilan Pidana Anak, Lembaran Negara Tahun 2012 Nomor 153, Tambahan Lembaran Negara Tahun 2012 Nomor 5332.

Undang-Undang Nomor 17 Tahun 2016 tentang Penetapan Peraturan Pemerintah Pengganti Undang-Undang Nomor 1 Tahun 2016 tentang
Perubahan Kedua Atas Undang-Undang Nomor 23 Tahun 2002 tentang Perlindungan Anak, Lembaran Negara Tahun 2016 Nomor 237, Tambahan Lembaran Negara Tahun 2016 Nomor 5882.

\section{Buku:}

Arief, Barda Nawawi, 1998, Beberapa Aspek Kebijakan dan Pengembangan Hukum Pidana, Bandung: Citra Aditya.

Bynum, Jack E. dan William E. Thompsson, 2002, Juvenile Delinquency a Social Approach, Boston: Allyn and Bacon A Peason Education Company. Farid, M. dkk., 2003, Pengertian Konvensi Hak Anak, Jakarta: UNICEF.

Gultom, Maidin, 2008, Perlindungan Hukum Terhadap Anak Dalam Sistem Peradilan Pidana Anak di Indonesia, Bandung: Refika Aditama.

Hadisuprapto, Paulus, 2003, "Pemberian Malu Reintegratif Sebagai Sarana Non Penal Penanggulangan Perilaku Delinkuensi Anak (Studi Kasus di Semarang dan Surakarta)", Disertasi Ilmu Hukum, Semarang, Universitas Diponegoro.

Harefa, Beniharmoni dan Vivi Ariyanti, 2016, Seputar Perkembangan Sistem Peradilan Pidana Anak dan Tindak Pidana Narkotika di Indonesia, Yogyakarta: Deepublish.

Herlina, Apong dkk., 2004, Perlindungan Terhadap Anakyang Berhadapan Dengan Hukum, Manual Pelatihan untuk Polisi, Jakarta: POLRI dan UNICEF.

Marzuki, Peter Mahmud, 2010, Penelitian Hukum (Edisi Revisi), Jakarta: Kencana Prenada Media Grup.

Purnianti, Mamik Sri Supatmi dan Ni Made Martini Tinduk, 2003, Analisa Sistem Peradilan Pidana Anak (Juvenile Justice System), Departemen Kriminologi, Jakarta: Fisip Universitas Indonesia-Unicef.

Soemitro, Ronny Hanitijo, 1998, Metode Penitian Hukum, Jakarta: Ghalia Indonesia.

Sudarto, 2010, Kapita Selekta Hukum Pidana, Bandung: Alumni.

\section{Jurnal:}

Wahyudi, Setya, Johannes Suhardjana, Kuat Puji Prayitno, dan Dwi Hapsari Retnaningrum, 
"Pengembangan Diversi Dalam Sistem Peradilan Pidana Anak sebagai Perlindungan dan Upaya Menghindari Pengaruh Buruk Proses Peradilan
Terhadap Anak", Jurnal Kertha Wicaksana, Vol. 15 No. 1, Januari 2009, Universitas Warmadewa Denpasar. 